\title{
The Effects of Ramadān Fasting on the Levels of Gonadotrophins
}

\author{
S.M. Bakir, ${ }^{\star}$ M.B.Ch.B., M.M.T. Kordy, ${ }^{\star}$ M.B.Ch.B., Ph.D., A.M.A. Gader, ${ }^{\star}$ M.B.B.S., Ph.D. \\ O. Karrar, ${ }^{* *}$ M.B.B.S., M.A., Ph.D. \\ Riyadh, Saudi Arabia
}

DOI: http://dx.doi.org/10.5915/24-1-15469

\begin{abstract}
FSH and LH levels were measured at 9:00 a.m., 4:00 p.m., 9:00 p.m. and 4:00 a.m. in eleven healthy subjects observing the dawn to sunset fast of the Muslim Holy Month of Ramadân. Similar measurements were undertaken in an ordinary non-fasting day for comparison.

Significant diurnal fluctuations of these hormones were noted. In a non-fasting day FSH levels peaked at 9:00 a.m., while the lowest level was at 9:00 p.m. During Ramadân, levels of FSH were highest at 4:00 a.m. $(3.29 \pm$ $2.72 \mathrm{IU} / \mathrm{L})$ and lowest at 9:00 a.m. $(1.28 \pm 0.27 \mathrm{IU} / \mathrm{L})$. The $\mathrm{LH}$ levels in an ordinary non-fasting day were highest at 9:00 a.m., while during Ramadän peak levels were noted at 4:00 a.m.

The significantly high gonadotrophin levels at 4:00 a.m. suggest that hypothalamic pituitary axis for gonadotrophin release exhibits peak activation in the early morning hours, more so in a Ramadän day than in a non-fasting day.
\end{abstract}

Key words: Ramadän, fasting, gonadotrophins

Fasting during the holy month of Ramadân entails the daily abstinence from food and drink from dawn to sunset, for approximately 15 hours. There are numerous studies on the biochemical as well as hematologic changes that accompany the Ramad̦an fast. $^{1-9}$ However, comparatively less information pertaining to changes in hormone levels is available. ${ }^{4,10}$ In spite of the scarcity of research on the effects of the Ramadan fast, most earlier studies were based on single estimations of the leutinizing hormones $(\mathrm{LH})$, and follicle stimulating hormone

From the Department of Physiology * and Biochemistry, ** College of Medicine and King Khalid University Hospital Riyadh 11461, Saudi Arabia.

Reprint Requests: Dr. S.M. Bakir

Department of Physiology

College of Medicine and King Khalid University Hospital P.O. Box 2925, Riyadh 11461, Saudi Arabia.
(FSH). This approach may not accurately reflect the dynamic alterations occurring throughout the day, in view of the changes in food intake and sleep during Ramadan as compared to an ordinary day.

This study aims at monitoring plasma levels of FSH and LH over a 24 hour period during an ordinary non-fasting day as well as fasting Ramadân day.

\section{Material and methods}

Eleven healthy volunteers were recruited from the teaching and technical staff and students at the College of Medicine, Riyadh. All were males aged between $24-46(34.9 \pm 1.6)$ years. Their weights ranged from 56 to $90 \mathrm{Kg}(72.4 \pm 10.4 \mathrm{Kg})$.

During Ramaḍân, abstention from food and drink is from dawn to sunset. The first meal (breakfast) is taken immediately after sunset, approximately at 6:00 p.m. and thereafter the subject is free to consume food and drink. Sleeping hours, which are between 11:00 p.m. and 8:00 a.m., are interrupted at 4:00 a.m. for the intake of a light meal and the dawn "Fajr" 
Table 1. FSH Levels in 11 healthy volunteers during a non-fasting compared to a fasting Ramadan day.

\begin{tabular}{c|ccccc}
\hline Time & $9: 00$ a.m. & $4: 00$ p.m. & $9: 00$ p.m. & 4:00 a.m. \\
\hline \multicolumn{5}{c}{ Non-fasting } \\
FSH (IU/L) & $1.71 \pm 0.50^{* *}$ & $1.40 \pm 0.34$ & $1.21 \pm 0.38$ & $1.25 \pm 0.36$ \\
& $\mathrm{~N}=11$ & $\mathrm{~N}=10$ & $\mathrm{~N}=10$ & $\mathrm{~N}=11$ \\
& & Fasting & \\
& $1.28 \pm 0.27$ & $1.30 \pm 0.43$ & $1.31 \pm 0.40$ & $3.29 \pm 2.72^{* *}$ \\
& $\mathrm{~N}=10$ & $\mathrm{~N}=11$ & $\mathrm{~N}=11$ & $\mathrm{~N}=11$ \\
\hline
\end{tabular}

$\dagger$ Mean \pm SD One way analysis of variance ${ }^{*}=\mathbf{P}<0.05^{* *}=\mathrm{P}<0.0001$

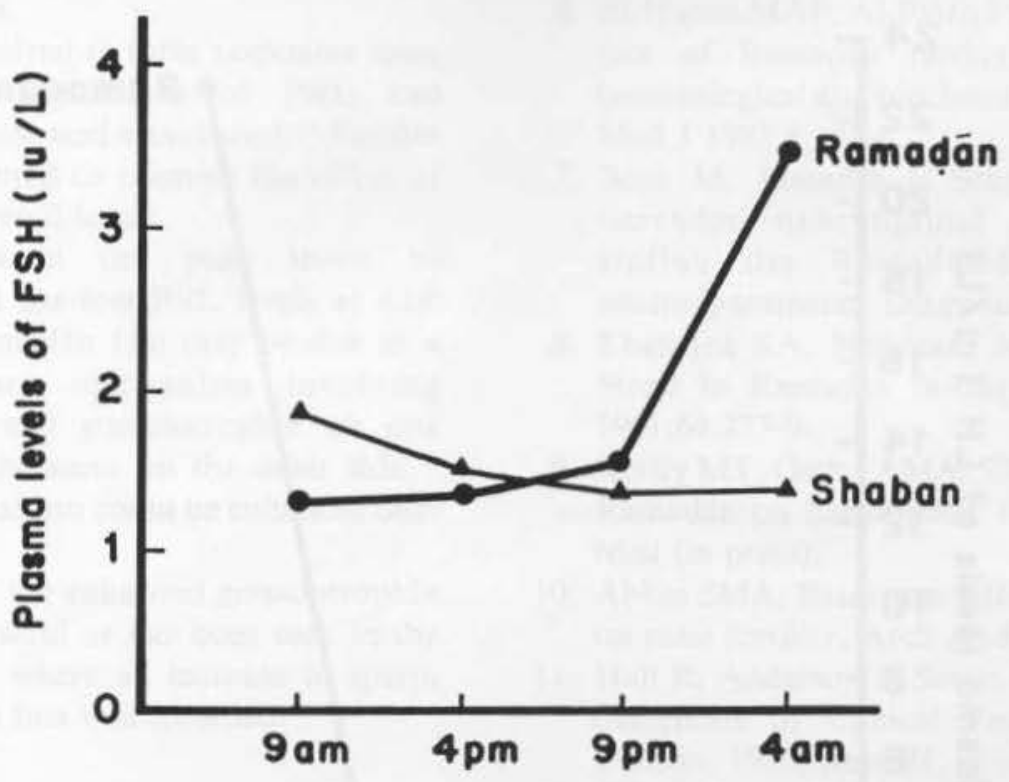

Figure 1a: Comparison between plasma levels of FSH during a non-fasting day (Sha'baản) versus a fasting day (Ramaḍān)

prayer. Daily working hours in Ramaḍān are from 9:00 a.m. to $3: 30$ p.m. Blood samples during Ramadān were collected in the middle of the month when adaptation to the change in food and sleep rhythm was assumed to be complete. In a non-fasting day, work starts at 7:30 a.m. and finishes at 4:30 p.m. Lunch is between 1:00 and 2:00 p.m., dinner is at 7:00 p.m. and bed-time is approximately 10:00 p.m. The subjects wake up at 4:30 a.m. for the dawn prayer, then remain awake until they go to work.

Consecutive blood samples over a 24 hour period were collected at 9:00 a.m., 4:00 p.m., 9:00 p.m. and 4:00 a.m. during both a non-fasting and a Ramadān day. Plasma was separated in a refrigerated $\left(4-8^{\circ} \mathrm{C}\right)$ centrifuge, and was stored at $-40^{\circ} \mathrm{C}$ until analysed. Hormone assays were conducted in a radioimmunoassay laboratory, where FSH and LH were assayed using RIA kits supplied by Pharmacia Diagnostics. All measurements were conducted in duplicate with appropriate quality control samples being simultaneously run.

The one way analysis of variance was employed to examine the significance of the differences in hormone levels at various time intervals. A P value of $<0.05$ was taken to be of significance.

\section{Results}

FSH: During a non-fasting day FSH levels peaked at 9:00 a.m. $(P<0.05)$. The other successive three measurements, taken through the rest of the day were of comparable magnitude. On the other hand, during a fasting day more marked fluctuations were noted; FSH levels reached maximum levels at 4:00 a.m. $(3.29 \pm 2.72 \mathrm{IU} / \mathrm{L}, \mathrm{P}<0.0005)$ and lowest levels at 9:00 a.m. (1.28 $\pm 0.27 \mathrm{IU} / \mathrm{L})$. Levels at 4:00 p.m. $(1.30 \pm 0.43 \mathrm{IU} / \mathrm{L})$ and $9: 00$ p.m. ( $1.31 \pm 0.4 \mathrm{IU} / \mathrm{L})$ were not significantly different. (Table 1, Figure 1a)

LH: During a non-fasting day, $\mathrm{LH}$ concentrations reached peak levels at 9:00 a.m. $(2.78 \pm 0.96 \mathrm{IU} / \mathrm{L})$ and were lowest at 9:00 p.m. (1.61 $\pm 0.51 \mathrm{IU} / \mathrm{L})$ $(\mathrm{P}<0.005)$. On the other hand, LH levels during a fasting Ramaḍan day, peaked at 4:00 a.m. (22.83 \pm $21.45 \mathrm{IU} / \mathrm{L})$ and were lowest at 9:00 a.m. (1.48 \pm $0.53)(P<0.0001)$. (Table 2, Figure $1 \mathrm{~b}$ ) 
Table 2. LH Levels in 11 healthy volunteers during a non-fasting day compared to a fasting Ramadân day.

\begin{tabular}{c|c|c|c|c}
\hline Time & $9: 00$ a.m. & $4: 00$ p.m. & $9: 00$ p.m. & $4: 00$ a.m. \\
\hline \multicolumn{5}{c}{ Non-fasting } \\
LH (IU/L) & $2.78 \pm 0.96 \dagger^{*}$ & $1.97 \pm 1.29$ & $1.61 \pm 0.51$ & $1.163 \pm 0.25$ \\
& $\mathrm{~N}=11$ & $\mathrm{~N}=10$ & $\mathrm{~N}=10$ & $\mathrm{~N}=11$ \\
& \multicolumn{5}{c}{ Fasting } \\
& $1.48 \pm 0.53$ & $1.963 \pm 0.50$ & $2.12 \pm 0.93$ & $22.83 \pm 21.4^{* * *}$ \\
& $\mathrm{~N}=10$ & $\mathrm{~N}=11$ & $\mathrm{~N}=11$ & $\mathrm{~N}=11$ \\
\hline
\end{tabular}

$\dagger$ Mean \pm SD One way analysis of variance. ${ }^{*}=\mathrm{P}<0.005^{* *}=\mathrm{P}<0.0001$

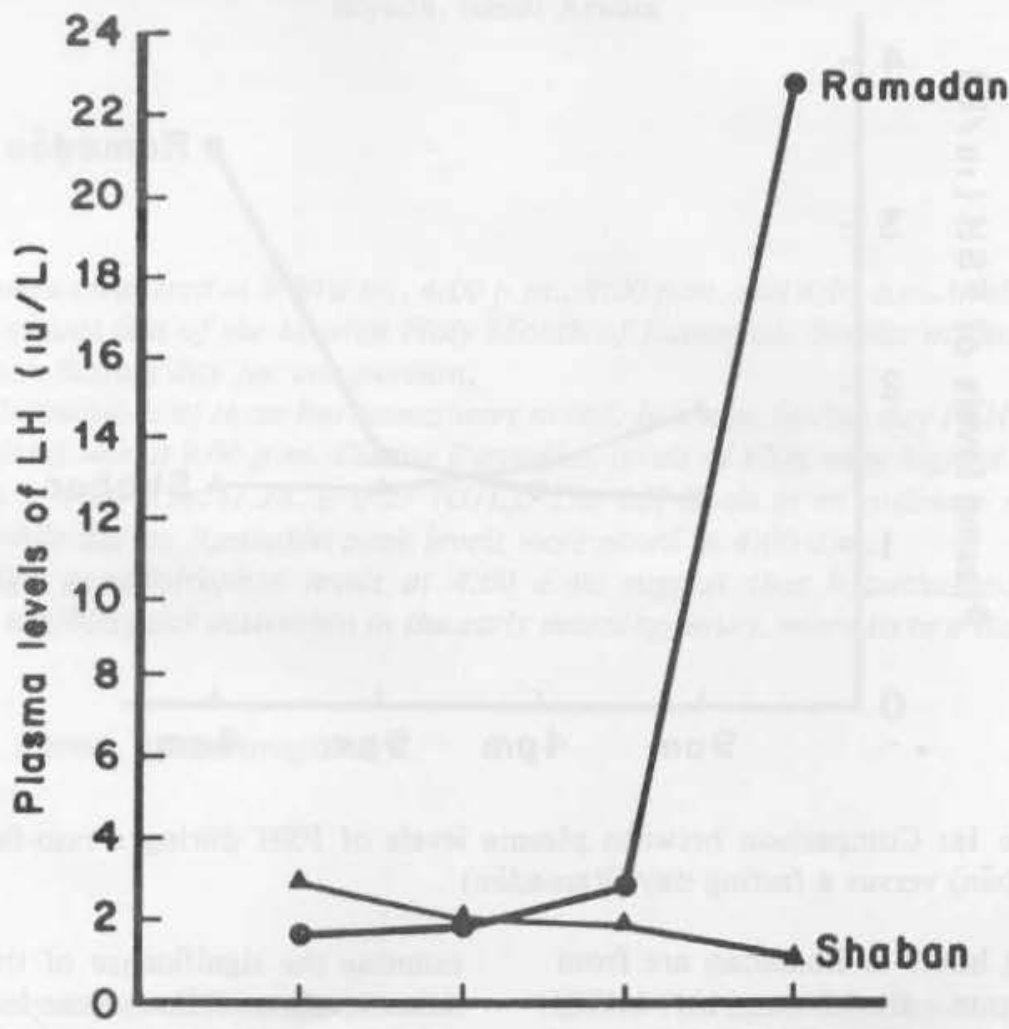

Figure 1b: Comparison between plasma levels of LH during a non-fasting day (Sha'bān) versus a fasting day (Ramaḍān)

\section{Discussion}

The mechanisms controlling the release of gonadotrophins are poorly understood. In males, only negative feedback influences are believed to operate and gonadotrophin secretion is relatively constant. ${ }^{12}$

This study shows significantly higher values for FSH and $\mathrm{LH}$ at 4:00 a.m. during the fasting month of Ramadān when compared to non-fasting measurements. In a previous study, 9 days starvation were accompanied by a blunt $\mathrm{LH}$ response during the starvation period. ${ }^{12}$ On refeeding, the level of LH was higher than that before the starvation program. On the other hand, FSH levels did not return to normal upon refeeding. The study attributed the blunted gonadotrophin response to altered sensitivity of the pituitary to hypothalamic control.
In the present study the level of gonadotrophins at $4: 00$ p.m. (which is about 12 hours after the commencement of fasting) were not significantly different from a non-fasting day. This finding contradicts other studies where starvation led to a reduction in LH and FSH levels. ${ }^{12}$ One study has looked into the effect of Ramadän fast on the levels of gonadotrophins; however, only single estimations were performed and these will not reflect the pulsatile nature of hormone release. ${ }^{10}$

Unpublished data indicate that low levels of prolactin (PRL) are recorded at 4:00 p.m. during Ramad̦an fast. ${ }^{13}$ It has also been suggested that the release of endogenous opiates, by suppressing hypothalamic dopamine secretion, mediate both an increase in PRL levels during exercise and an inhibition of the pulsatile secretion of gonadotrophin 
release hormones. ${ }^{14,15}$ Others have shown that $\mathrm{LH}$ is under inhibitory opioid control both in normal subjects and in widely differing pathological states of gonadotropic axis. ${ }^{16}$ Additionally, dynamic studies of endorphins levels show that peak values occur between 4:00 a.m. and 10:00 a.m. ${ }^{17}$

To explain the high values of gonadotrophins which were recorded at 4:00 a.m. during Ramaḍân in this study we propose the following mechanisms:

1. An enhanced early morning responsiveness in the hypothalamic-pituitary axis since Ramadân fast is an intermittent daily fast unlike prolonged starvation lasting few days.

2. Opioids may be involved in these responses since their role in the regulations of PRL and gonadotrophins is now well-established. ${ }^{16}$ Further studies may be required to examine the effect of Ramaḍan fast on opioid levels.

3. The overlap between the peak levels of gonadotrophins and the low PRL levels at 4:00 a.m. during the Ramaḍan fast may be due to a common regulatory mechanism involving pituitary prolactin and gonadotrophin on one side, and the hypothalamus on the other side. ${ }^{13}$ Such a control mechanism could be enhanced during Ramaḍān.

It is unclear whether the enhanced gonadotrophin response is clinically useful as has been seen in the study of Abbas et al, where an increase in sperm count during Ramaḍan fast was recorded. ${ }^{10}$

\section{Acknowledgement}

We would like to thank Sheikh Abdul-Majeed A. Azzindani, Director of Project of Scientific Miracle in the Qur'ann and Hadith, for financial support. The project is also partly supported by a grant from the College of Medicine Research Centre (CMRC). We are grateful to Messrs. Mohamed A. Babiker from the Biochemistry Department Hormone Laboratory for his excellent technical assistance, Mohammed Akram for typing the manuscript and Mrs. F. Chatila for analysis of the results. A special tribute is also due to the volunteers who participated in this study.

\section{References}

1. Gumaa KA, Mustafa KY, Mahmoud NA, Gader AMA: The effects of fasting in Ramaḍan: Serum uric acid and lipid concentrations. Br J Nutr 1978;40:573-81.

2. Mustafa KY, Mahmoud NA, Gumaa KA, Gader AMA: The effects of fasting in Ramaḍann: Fluid and electrolyte balance. $\mathrm{Br} \mathrm{J}$ Nutr 1978; 40:583-9.

3. Scott TG: The effect of the Muslim fast of Ramad̦an on routine laboratory investigations. King Abdulaziz Medical Journal 1981;1:23-35.

4. Fedail SS, Murphy D, Salih SY, Bolton $\mathrm{CH}$, Harvey RF: Changes in certain blood constituents during Ramaḍân. Am J Clin Nutr 1982; 36:350-3.

5. Shoukry MI: Effect of fasting in Ramadān on plasma lipoproteins and apoproteins. Saudi Med J 1986;7:561-5.

6. El-Hazmi MAF, Al-Faleh FZ, Al-Mofleh IA: Effect of Ramadān fasting on the values of hematological and biochemical parameters. Saud Med J 1987;8:171-6.

7. Born M, Elmadfa I, Schmahl FW: Intermittierender nahrungsund flussigkeitsentzug: einflub des Ramaḍăn-fastens auf stoffwechselparameter. Diagnostik 1980;13:97-100.

8. Khaleque KA, Muazzam MG, Chowdhury RI: Stress in Ramadạn fasting. J Trop Med Hyg 1961;64:277-9.

9. Kordy MT, Gader AMA. The effect of fasting in Ramaḍān on haemostatic variables. Ann Saudi Med (in press).

10. Abbas SMA, Basalama: Effects of Ramadān fast on male fertility. Arch Androl 1985;16: 161-6.

11. Hall R, Anderson J, Smart G, Besser GM: Fundamentals of Clinical Fendocrinology. Third Edition, 1980, page 27.

12. Kilbanski A, Beitnins IZ, Badger T, Little R, McArthur JW: Reproductive functions during fasting in men. J Clin Endocrin Metab 1981 53:258-63.

13. Bakir SM et al. (unpublished).

14. Wardlaw SL, Frantz AG: Effect of swimming stress on brain B-endorphin and ACTH. Clin Res 1980;28:482A.

15. Shyu BC, Anderson SA, Thoren P: Endorphin mediated increase in pain threshold induced by long lasting exercise in rats. Life Science 1982; 30:833-40.

16. Lightman SL, Jacobs HS, Maguire AK et al.: Constancy of opioid control of leutinizing hormone in different patho-physiological states. J Clin Endocrinol Metabol, 1981;52;6:1260-63.

17. Robert RM, Guilleminault DC, Albert LH et al.: Diurnal rhythm of plasma immuno reactive B-endorphin and its relationship to sleep stages and plasma rhythms of cortisol and prolactin. J Clin Endocrinol and Metabol 1981;52:942-7. 